\title{
XXXV. Quantitative relation between molecular conductivities
}

\section{Philip Blackman}

To cite this article: Philip Blackman (1906) XXXV. Quantitative relation between molecular conductivities, Philosophical Magazine Series 6, 11:63, 416-418, DOI: 10.1080/14786440609463458

To link to this article: http://dx.doi.org/10.1080/14786440609463458

曲 Published online: 16 Apr 2009.

Submit your article to this journal $[\pi$

Џ Article views: 2

Q View related articles $\square$

Citing articles: 1 View citing articles 5 
This result is really included in Schuster's formula when we examine the meaning of the term $\psi$.

Hitherto this has always been interpreted to mean in every case the angle subtended by the collimator-lens at the slit. But it is clear that by tilting the prism or grating sufficiently, only part of the beam passing through the lens is effective. Reference to the proof of the formula * shows that in that case it is only the width of the effective portion which should be considered in determining the value of the angle $\psi$.

Hence that angle really depends on the position of the prism or grating, and may in the limit be reduced to zero. The smaller $\psi$ is, the greater is the purity, and ultimately by reducing its value the full resolving power is reached with a great width of slit.

This is confirmed by experiment, and $I$ find that with a small Thorp grating containing between 1300 and 1400 lines it is easily possible to separate the sodium D-lines even when the slit is half a centimetre wide; in fact in most cases the collimator can be entirely omitted.

The application of this device is limited by the great loss of light by reflexion at the surface of the grating when large angles of incidence are used.

Cases, however, do occur where the principle may be used with advantage. For example, it is very convenient in the photometry of arc-lamps when using the Vierordt colourphotometer, where large errors are introduced, notably in the red end of the spectrum, owing to differences in the purity of the two spectra under comparison.

Physical Laboratory, Manchester.

XXXV. Quantitative Relation between Molecular Conducticities. By Philip Blackman †.

THE formation of a salt MX from the acid HX and the base $\mathrm{MOH}$ maly be represented by the equation

$$
\mathrm{H}^{\bullet}+\mathrm{X}^{\prime}+\mathrm{M}^{\bullet}+\mathrm{OH}^{\prime}=\mathrm{M}^{\bullet}+\mathrm{X}^{\prime}+\mathrm{HOH} \text {. }
$$

The initial and final electrical states differ by the expression $\mathrm{H}^{\circ}+\mathrm{OH}^{\prime}=\mathrm{H} . \mathrm{OH}$; hence, we should expect in the formation of the salt the disappearance of electrical conductivity equivalent to that required by the above equation.

This quantity of electrical conductivity will depend on

* Kayser, Handbuch der Spectroscopie, vol. i. p. 552.

+ Communicated by the Author. 
(1) the temperature, (2) the molecular concentration, and (3) the nature of the acid. Supposing these three conditions be fixed, there ought to be a constant quantity for the electrical conductivity corresponding to $\mathrm{H}^{\bullet}+\mathrm{OH}^{\prime}=\mathrm{H} . \mathrm{OH}$.

Let $\mu v_{\mathrm{HI}}, \mu v_{\mathrm{M}_{1} \mathrm{OH}}, \mu v_{\mathrm{N}_{2} \mathrm{OII}}, \mu v_{\mathrm{M}_{1} \mathrm{x}}, \mu v_{\mathrm{M}_{2} \mathrm{x}}$, represent the molecular conductivities (all measured at the same molecular concentration $v$, and at the same temperature) of the acid $\mathrm{HX}$, of the bases $\mathrm{M}_{1} \mathrm{OH}$ and $\mathrm{M}_{2} \mathrm{OH}$, and of the salts $\mathrm{M}_{1} \mathrm{X}$ and $\mathrm{M}_{2} \mathrm{X}$ respectively. Then, according to the above,

$$
\begin{aligned}
& \mu v_{\mathrm{IIX}}+\mu v_{\mathrm{MI}_{1} \text { OII }}=\mu v_{\mathrm{N}_{1} \mathrm{x}}+\mathrm{K}, \\
& \mu v_{\mathrm{IIX}}+\mu v_{\mathrm{N}_{2} \text { OII }}=\mu v_{\mathrm{N}_{2} \mathrm{X}}+\mathrm{K},
\end{aligned}
$$

where $\mathrm{K}$ is a constant.

$$
\text { Hence } \quad \mu v_{\mathrm{HX}}+\mu v_{\mathrm{S}_{1} \mathrm{OH}}-\mu v_{\mathrm{M}_{1} \mathrm{X}}=\mu v_{\mathrm{IIX}}+\mu v_{\mathrm{N}_{2} \text { OII }}-\mu v_{\mathrm{S}_{2} \mathrm{X}} \text {. }
$$

The following values, calculated from the data in the

\begin{tabular}{|c|c|c|c|c|c|c|c|c|}
\hline$v\left(\right.$ at $\left.18^{\circ}\right)=$ & 1. & 2. & 10. & 32. & 100. & 1000. & 1024. & 10,000 \\
\hline 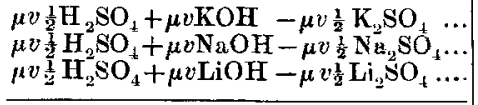 & $\begin{array}{l}287 \\
\mathbf{2 8 4} \\
\mathbf{2} 68\end{array}$ & $\begin{array}{l}300 \\
297 \\
282 \\
\end{array}$ & $\begin{array}{l}317 \\
305 \\
314 \\
\end{array}$ & $\begin{array}{l}418 \\
420 \\
419 \\
\end{array}$ & $\begin{array}{l}387 \\
381 \\
390\end{array}$ & $\begin{array}{l}422 \\
413 \\
\cdots \\
\end{array}$ & $\begin{array}{r}468 \\
481 \\
482 \\
\end{array}$ & $\begin{array}{l}470 \\
461\end{array}$ \\
\hline $\begin{array}{lr}\mu v \mathrm{HNO}_{3}+\mu v \mathrm{KOH} & -\mu v \mathrm{KNO}_{3} \ldots . . \\
\mu v \mathrm{HNO}_{3}+\mu v \mathrm{NuOH}_{3}-\mu v \mathrm{NaNO}_{3} \ldots \\
\mu v \mathrm{HNO}_{3}+\mu v \frac{1}{3} \mathrm{BaO}_{2} \mathrm{H}_{2}-\mu v \frac{1}{2} \mathrm{BaN}_{2} \mathrm{O}_{6} .\end{array}$ & $\begin{array}{c}374 \\
364 \\
\cdots\end{array}$ & $\begin{array}{l}\cdots \\
\cdots \\
\cdots\end{array}$ & $\begin{array}{l}4: 33 \\
411\end{array}$ & $\begin{array}{l}492 \\
491 \\
473\end{array}$ & $\begin{array}{c}441 \\
428 \\
\cdots\end{array}$ & $\begin{array}{l}439 \\
429 \\
\cdots\end{array}$ & $\begin{array}{l}485 \\
494 \\
481\end{array}$ & $\begin{array}{l}490 \\
480\end{array}$ \\
\hline 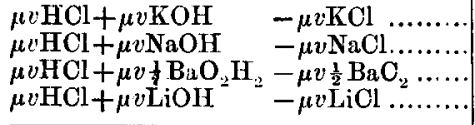 & $\begin{array}{c}358 \\
358 \\
344\end{array}$ & \begin{tabular}{l|}
$\cdots$ \\
$\cdots$ \\
$\cdots$ \\
$\cdots$
\end{tabular} & \begin{tabular}{|l|}
418 \\
408 \\
$\cdots$ \\
$\cdots$
\end{tabular} & $\begin{array}{l}490 \\
492 \\
470 \\
493\end{array}$ & $\begin{array}{c}439 \\
433 \\
\ldots \\
442\end{array}$ & $\begin{array}{l}437 \\
425 \\
\cdots \\
\cdots\end{array}$ & $\begin{array}{l}489 \\
490 \\
490 \\
491\end{array}$ & $\begin{array}{l}48.5 \\
479\end{array}$ \\
\hline 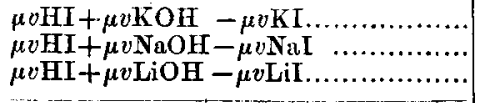 & $\begin{array}{l}\cdots \\
\cdots \\
\cdots\end{array}$ & $\begin{array}{l}\cdots \\
\cdots \\
\cdots\end{array}$ & $\begin{array}{l}426 \\
427 \\
411 \\
\end{array}$ & & & & & \\
\hline $\begin{array}{l}\mu v \mathrm{HIO}_{3}+\mu v \mathrm{KOH}-\mu v \mathrm{KIO}_{3} . \\
\mu v \mathrm{HIO}_{3}+\mu v \mathrm{NaOH}-\mu v \mathrm{NaIO}_{3}\end{array}$ & $\ldots$ & $\begin{array}{l}\ldots \\
\ldots\end{array}$ & $\ldots$ & $\begin{array}{l}442 \\
441\end{array}$ & $\begin{array}{l}\cdots \\
\cdots\end{array}$ & $\ldots$ & $\begin{array}{l}482 \\
481\end{array}$ & \\
\hline
\end{tabular}
'Physikalisch-Chemische Tabellen, von Landolt und Börnstein" *, illustrate the above:-

'The last equation, by subtracting the common term $\mu r_{\mathrm{HX}}$ and then by transposing, becomes

The equation

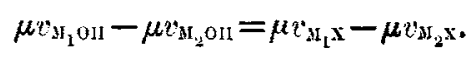

$$
\mu v_{\mathrm{M}_{1} \mathrm{OII}}-\mu v_{\mathrm{N}_{2} \mathrm{OII}}=\mu v_{\mathrm{M}_{2} \mathrm{x}}-\mu v_{\mathrm{M}_{2} \mathrm{x}},
$$

* The table, which was first drawn up from an earlier edition of Landolt-Bürnstein, has been corrected by means of the latest (1905) edition recently published. 
it will be at once noticed, furnishes a means of calculating the molecular conductivities of (1) insoluble or unstable kases, and (2) insoluble or unstable salts, the molecular conductivities of which cannot be determined by direct measurement.

Similarly, it can be shown that

$$
\begin{aligned}
\mu v_{\mathrm{M}_{1} 0 \mathrm{II}}-\mu v_{\mathrm{M}_{2} 0 \mathrm{II}} & =\mu v_{\mathrm{M}_{1} \mathrm{x}_{1}}-\mu v_{\mathrm{M}_{2} \mathrm{x}_{1}} \\
& =\mu v_{\mathrm{M}_{1} \mathrm{x}_{2}}-\mu v_{\mathrm{M}_{2} \mathrm{x}_{2}} \\
& =\cdots \cdots= \\
\mu v_{\mathrm{MI}_{1} \mathrm{x}}-\mu v_{\mathrm{M}_{2} \mathrm{X}} & =\mu v_{\mathrm{M}_{1} \mathrm{x}_{1}}-\mu v_{\mathrm{M}_{2} \mathrm{x}_{1}} \\
& =\mu v_{\mathrm{M}_{1} \mathrm{x}_{2}}-\mu v_{\mathrm{M}_{2} \mathrm{x}_{2}} \\
& =\mu v_{\mathrm{M}_{1} \mathrm{x}_{3}}-\mu v_{\mathrm{M}_{2} \mathrm{x}_{3}} \\
& =\ldots \ldots \ldots . \\
& =\text { constant. }
\end{aligned}
$$

Hence

This final equation, it will be observed, is identical with the hitherto unexplained fact discovered by Kohlrausch (and further extended by Ostwald, see Lehrb. der Alg. Chemie, ii.).

Eist I.ondon Technical College,

London, E.

XXXVI. Notices respecting New Books.

Irvns, Electrons, Corpuscules. Mémoires réunis et publiés par H. Abraham et P. Langevin. Paris: Gauthier-Villars. 1905. Premier Fascicule, pp. xvi +512 . Second Fascicule, pp. 513-1138.

IF any proof were needed of the extent to which the modern 1 theory of electrons dominates physical science, it might, not inappropriately, be regarded as furnished by the publication of the two large volumes under review. The Société Française de Physique, which has already done good work in rendering accossible to numerous readers collections of important memoirs on various branches of physics (issued under the title of Collection de Mémoires sur la Physique), has performed another most useful service by collecting all the scattered papers dealing with the rise and development of the electronic idea, and arranging them in a form which renders it an easy matter to look up the particular contributions towards any branch of the subject made by different investigators.

Originally, the work was to have been edited by the late M. Alfred Potier (to whose memory it is dedicated), but owing to 